\title{
Microbial Community Analysis of a Coastal Salt Marsh Affected by the Deepwater Horizon Oil Spill
}

\author{
Melanie J. Beazley ${ }^{1}$, Robert J. Martinez ${ }^{1}$, Suja Rajan ${ }^{1}$, Jessica Powell ${ }^{1}$, Yvette M. Piceno ${ }^{2}$, Lauren M. Tom ${ }^{2}$, \\ Gary L. Andersen ${ }^{2}$, Terry C. Hazen ${ }^{3}$, Joy D. Van Nostrand ${ }^{4}$, Jizhong Zhou ${ }^{4}$, Behzad Mortazavi ${ }^{1,5}$, \\ Patricia A. Sobecky ${ }^{1 *}$
}

1 Department of Biological Sciences, University of Alabama, Tuscaloosa, Alabama, United States of America, 2 Lawrence Berkeley National Laboratory, Berkeley, California, United States of America, 3 Department of Microbiology, University of Tennessee, Knoxville, Tennessee, United States of America, 4 Institute for Environmental Genomics, University of Oklahoma, Norman, Oklahoma, United States of America, $\mathbf{5}$ Dauphin Island Sea Lab, Dauphin Island, Alabama, United States of America

\begin{abstract}
Coastal salt marshes are highly sensitive wetland ecosystems that can sustain long-term impacts from anthropogenic events such as oil spills. In this study, we examined the microbial communities of a Gulf of Mexico coastal salt marsh during and after the influx of petroleum hydrocarbons following the Deepwater Horizon oil spill. Total hydrocarbon concentrations in salt marsh sediments were highest in June and July 2010 and decreased in September 2010. Coupled PhyloChip and GeoChip microarray analyses demonstrated that the microbial community structure and function of the extant salt marsh hydrocarbon-degrading microbial populations changed significantly during the study. The relative richness and abundance of phyla containing previously described hydrocarbon-degrading bacteria (Proteobacteria, Bacteroidetes, and Actinobacteria) increased in hydrocarbon-contaminated sediments and then decreased once hydrocarbons were below detection. Firmicutes, however, continued to increase in relative richness and abundance after hydrocarbon concentrations were below detection. Functional genes involved in hydrocarbon degradation were enriched in hydrocarbon-contaminated sediments then declined significantly $(p<0.05)$ once hydrocarbon concentrations decreased. A greater decrease in hydrocarbon concentrations among marsh grass sediments compared to inlet sediments (lacking marsh grass) suggests that the marsh rhizosphere microbial communities could also be contributing to hydrocarbon degradation. The results of this study provide a comprehensive view of microbial community structural and functional dynamics within perturbed salt marsh ecosystems.
\end{abstract}

Citation: Beazley MJ, Martinez RJ, Rajan S, Powell J, Piceno YM, et al. (2012) Microbial Community Analysis of a Coastal Salt Marsh Affected by the Deepwater Horizon Oil Spill. PLoS ONE 7(7): e41305. doi:10.1371/journal.pone.0041305

Editor: Mark R. Liles, Auburn University, United States of America

Received March 15, 2012; Accepted June 19, 2012; Published July 18, 2012

This is an open-access article, free of all copyright, and may be freely reproduced, distributed, transmitted, modified, built upon, or otherwise used by anyone for any lawful purpose. The work is made available under the Creative Commons CCO public domain dedication.

Funding: This work was supported by National Science Foundation-CBET (RAPID 1042743) and Dauphin Island Sea Lab/Marine Environmental Science Consortium $2423 \mathrm{Jv}$, T4-005UA. The funders had no role in study design, data collection and analysis, decision to publish, or preparation of the manuscript.

Competing Interests: The authors have declared that no competing interests exist.

*E-mail: psobecky@as.ua.edu

\section{Introduction}

The explosion and sinking of the Deepwater Horizon drilling rig on April 20, 2010 released an estimated 4.9 million barrels of crude oil $[1,2,3]$ and an estimated $1.7 \times 10^{11} \mathrm{~g}$ of volatile hydrocarbons [4] into the northern Gulf of Mexico (GoM). Crude oil reached the coast of Alabama by June 2010 and after approximately one month at sea the oil that impacted coastal areas was weathered and presented in the form of oil sheens and tar balls/mats $[5,6]$.

Coastal wetlands are among the most productive habitats in the world that act as nurseries for fisheries, sinks for anthropogenic contaminants, and provide protection from shoreline erosion [7]. Wetland environments are highly sensitive to oil contamination due to low tidal wave energy and the presence of marsh grasses that allow pollutants to remain sequestered in coastal sediments for years $[8,9]$. Traditional mechanical remediation processes, such as low-pressure flushing and vacuum/pumping, may adversely affect marsh environments or irreparably damage these sensitive ecosystems $[10,11]$. Two coastal marshes equally affected by heavy oiling from the Amoco Cadiz in 1978 were compared after one site received aggressive cleaning and the other was left untouched. Fifteen years later the cleaned marsh showed $\sim 30 \%$ decrease in vegetative area compared to a $21 \%$ increase in the size of the marsh that did not receive cleanup [12]. Thus, in many cases natural attenuation through microbial oil biodegradation processes is a preferred course of action in contaminated salt marshes to limit or prevent long-term habitat loss.

A number of environmental factors can enhance or limit natural attenuation or in situ bioremediation of oil, including temperature, salinity, nutrient availability, oxygen, physical state of the oil, and the natural microbial community [13]. Biodegradation of hydrocarbons is enhanced at higher temperatures (during summer months) when microbial activity is increased and oil viscosity is lower when compared to winter months. Tar balls and/or mousse are less viscous at higher temperatures and have more surface area available for physical breakdown and/or microbial degradation within sediments [14]. The most rapid rates of microbial hydrocarbon degradation occur under aerobic conditions when compared to anaerobic hydrocarbon degradation [15,16]. Inorganic nutrients (e.g. nitrogen, phosphorus, and iron) essential for microbial hydrocarbon degradation are replete in many marsh systems (due to land run-off). Another critical factor affecting the 

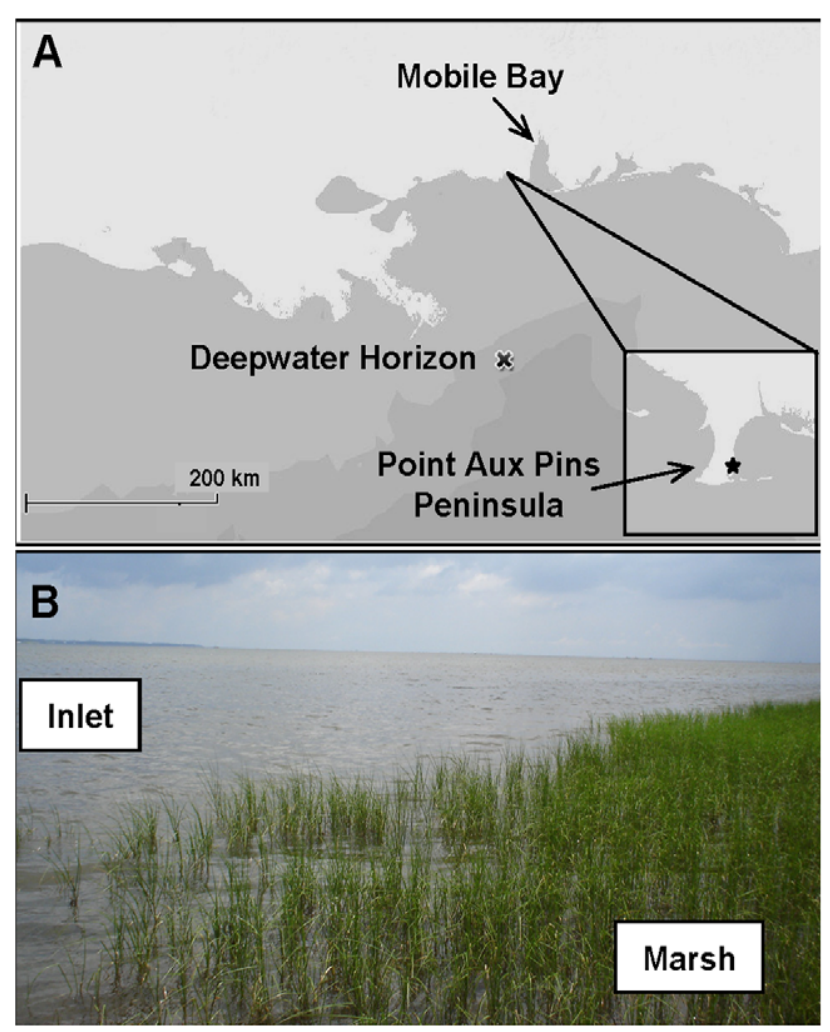

Figure 1. Study site. (A) Map of Point Aux Pins peninsula. Study site indicated by box in inset. (B) Sediment samples collected $\sim 25 \mathrm{~m}$ from shore outside the marsh stands (designated "Inlet") and 2-4 m from shore within the marsh stands (designated "Marsh"). doi:10.1371/journal.pone.0041305.g001

bioremediation of oil is the structure of the natural microbial community. Within GoM coastal ecosystems, microbial communities have adapted to hydrocarbon exposure as a result of chronic release from natural hydrocarbon seeps $[17,18,19,20,21]$. Thus, these GoM microbial communities represent a unique contrast to those present within coastal ecosystems that do not have exposure to hydrocarbon release.

There is a paucity of information regarding the in situ structure and function of salt marsh microbial communities in coastal GoM environments impacted by oil contamination. To date, studies that examine the microbial response to the Deepwater Horizon oil spill have described beach [22,23] and open ocean [2,24,25,26,27] environments. To the best of our knowledge, salt marsh microbial community structure and function have not been characterized by high-density PhyloChip and GeoChip microarray analyses. These high throughput culture-independent analyses have been shown to identify a greater microbial diversity in environmental samples compared to traditional sequencing of clone libraries [28]. Therefore, the goal of this study was to employ microarray-based methods to characterize the changes to the microbial community within a coastal salt marsh during and after oiling from the Deepwater Horizon.

\section{Materials and Methods}

\section{Study Site}

The salt marsh study site was located on the eastern side of the Point Aux Pins peninsula, southwest of Bayou La Batre, Alabama $\left(30^{\circ} 22^{\prime} \mathrm{N}\right.$; $\left.88^{\circ} 18^{\prime} \mathrm{W}\right)$ (Figure 1a). The marsh is dominated by funcus roemerianus and bordered by Spartina alterniflora along the outer edge. The rush stands extend approximately $10 \mathrm{~m}$ out from the shoreline. Water column depth during summer months was approximately $1 \mathrm{~m}$. Tides are diurnal (daily) and of moderate energy and amplitude $(\sim 0.38 \mathrm{~m})$ [29]. No specific permits or permissions were required for the described field studies at this location, which is not privately-owned or protected, and the field studies did not involve endangered or protected species.

\section{Sample Collection and Processing}

Triplicate sediment cores $(30 \mathrm{~cm} ; 7.3 \mathrm{~cm}$ I.D.) were collected within the marsh stands (designated "Marsh") approximately 2$4 \mathrm{~m}$ from shore and outside the stands approximately $25 \mathrm{~m}$ from the shoreline (designated "Inlet") (Figure 1b). Sediment cores were collected from the same location within the salt marsh during each sampling period. All samples were stored at $4{ }^{\circ} \mathrm{C}$ and $-80^{\circ} \mathrm{C}$ prior to processing. Sampling occurred on June 8, July 2, and September 10, 2010. Tar balls and tar mats mixed with wrack (organic debris) were collected in triplicate along the marsh fringe and shoreline on July 2, 2010. Sediment cores were aseptically extruded in $2 \mathrm{~cm}$ sections with the $0-2 \mathrm{~cm}$ and $8-10 \mathrm{~cm}$ sections used for analysis. Inlet water column temperature, salinity, dissolved oxygen, total dissolved solids, and $\mathrm{pH}$ were measured with a handheld YSI 556 multiprobe meter (YSI Incorporated, Yellow Springs, Ohio USA).

\section{DNA Extraction}

Genomic DNA was extracted in triplicate from $1 \mathrm{~g}$ sediment with an MP Biomedicals FastDNA spin kit for soils (MP Biomedicals, Solon, $\mathrm{OH}$ ) according to the manufacturer's protocol. DNA concentrations were measured via absorption at 260 nm using a NanoDrop ND-1000 (Thermo Scientific, Beverly, MA).

Table 1. Point Aux Pins salt marsh inlet water column physical and chemical parameters.

\begin{tabular}{llll}
\hline & & & \\
\hline & June 8, 2010 & July 2, 2010 & September 10, 2010 \\
\hline Temperature (') & 34.3 & 30.2 & 34.4 \\
Salinity (ppt) & 17.0 & 15.1 & 22.4 \\
Total Dissolved Solids $\left(\mathbf{g ~ L}^{-\mathbf{1}}\right.$ ) & 18.1 & 15.5 & 23.3 \\
pH & 8.48 & 7.49 & 8.39 \\
Dissolved Oxygen (\%) & 141.2 & 84.9 & 110.4 \\
\hline
\end{tabular}

Dissolved oxygen concentrations reported relative to $100 \%$ air saturation.

doi:10.1371/journal.pone.0041305.t001 
Table 2. Total petroleum hydrocarbons (TPH) detected in one or replicate samples.

\begin{tabular}{|c|c|c|c|}
\hline Sample Location & Date collected & Sediment Depth (cm) & Total Petroleum Hydrocarbons $\left(\mathrm{mg} \mathrm{kg}^{-1}\right)$ \\
\hline Tar balls & July 2010 & - & 20,300 \\
\hline Inlet & June 2010 & $0-2$ & $\mathrm{BD}, \mathrm{BD}, \mathrm{BD}$ \\
\hline Inlet & June 2010 & $8-10$ & $\mathrm{BD}, 36,145$ \\
\hline Inlet & July 2010 & $0-2$ & $\mathrm{BD}, \mathrm{BD}, 164$ \\
\hline Inlet & July 2010 & $8-10$ & $\mathrm{BD}, 32,64$ \\
\hline Inlet & Sept 2010 & $0-2$ & $48,49,56$ \\
\hline Inlet & Sept 2010 & $8-10$ & $\mathrm{BD}, \mathrm{BD}$ \\
\hline Marsh & June 2010 & $0-2$ & $47,54,189$ \\
\hline Marsh & June 2010 & $8-10$ & $34,38,175$ \\
\hline Marsh & July 2010 & $0-2$ & $53,66,163$ \\
\hline Marsh & July 2010 & $8-10$ & $\mathrm{BD}, 31,33$ \\
\hline Marsh & Sept 2010 & $0-2$ & $\mathrm{BD}, \mathrm{BD}, \mathrm{BD}$ \\
\hline Marsh & Sept 2010 & $8-10$ & $\mathrm{BD}, \mathrm{BD}, \mathrm{BD}$ \\
\hline
\end{tabular}

*BD indicates total petroleum hydrocarbons were below limit of detection.

doi:10.1371/journal.pone.0041305.t002

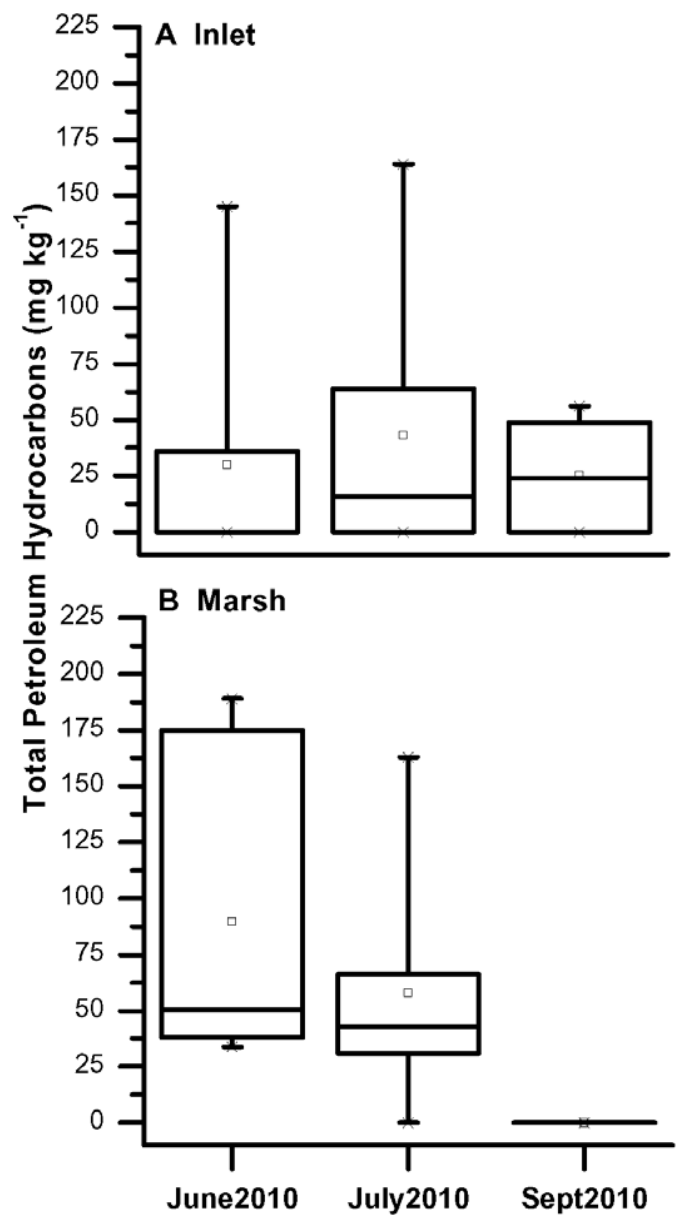

Figure 2. Boxplots of TPH concentrations in (a) Inlet and (b) Marsh surface and subsurface sediments. Each box represents the concentration range of $50 \%$ of the observations. Lines within the boxes represent the median values, open squares are the averages, and the whisker lines connect to outliers.

doi:10.1371/journal.pone.0041305.g002
PCR Amplification of $16 \mathrm{~S}$ rRNA Genes and Microarray Analysis (PhyloChip and GeoChip)

Polymerase chain reaction (PCR) of $16 \mathrm{~S}$ rRNA genes was performed with universal Bacteria (27F and 1492R) primers. Reagents for all PCR reactions and thermocycling conditions for bacterial 16S rRNA genes were performed as previously described [27], except that bacterial product was amplified in 25 cycles (instead of 30 cycles). Bacterial 16S rRNA gene diversity was assessed for June, July, and September 2010 sediments using the G3 PhyloChip, an Affymetrix platform microarray. The G3 PhyloChip contains over 1 million probes and can identify up to nearly 60,000 operational taxonomic units (OTUs). OTUs were scored as "present" when at least two of the three replicate core samples contained the OTU. Microarray sample preparation, hybridization, and scaling were performed as previously described [27]. Microbial functional gene analysis was conducted using the GeoChip 2.0 for June and July 2010 sediment samples. The GeoChip 2.0 microarray contains probes for $>10,000$ genes in $>150$ functional groups [30,31]. Microarray sample preparation, hybridization, and normalization were performed on triplicate samples as previously described [30,32]. Data analyses were performed with Primer-E software (version 6.1.13, Plymouth Marine Laboratory). Non-metric multi-dimensional scaling (nMDS) ordination of the bacterial community data was generated from a Bray Curtis resemblance matrix based on the mean relative abundance of taxa identified by PhyloChip in triplicate cores. Student's $t$-test and analysis of similarities (ANOSIM) were performed for sample comparisons.

\section{Hydrocarbon Analysis}

Total petroleum hydrocarbons (TPH) were extracted from sediment (30-60 g) collected in June, July, and September according to the EPA SM5520 method and analyzed by Fourier transform infrared spectroscopy (FTIR). TPH detection limit was $20 \mathrm{mg} \mathrm{kg}^{-1}$ for sediment samples. Tar balls and selected sediment samples $(30-60 \mathrm{~g})$ were extracted for $n$-alkanes with methylene chloride and analyzed by gas chromatography-mass spectrometry (GCMS). The crude oil calibration curve was generated using a sample of Macondo oil (MC252) collected from the wellhead (provided by $\mathrm{T}$. Hazen courtesy of $\mathrm{BP}$ ). All hydrocarbon 

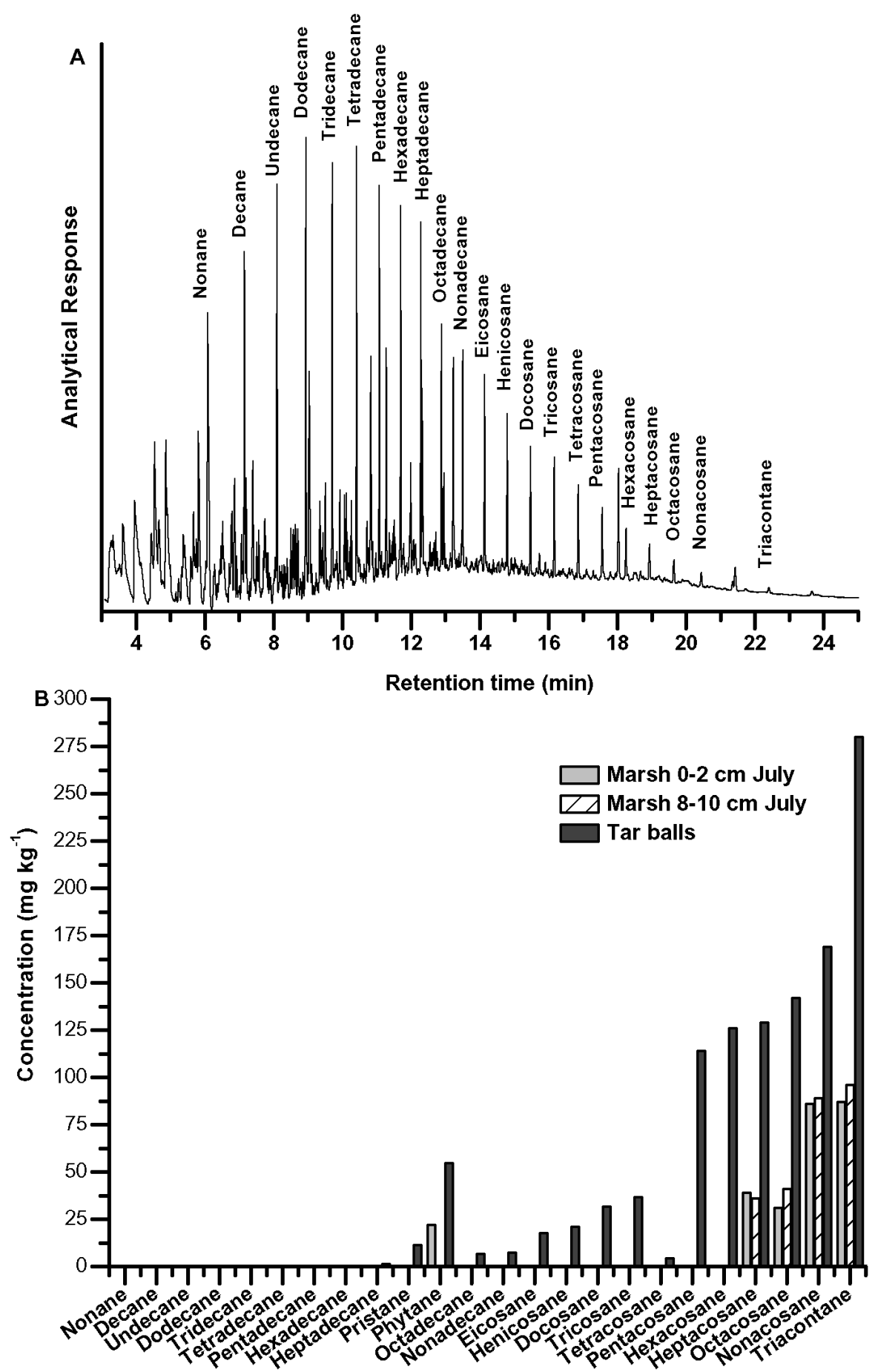

Figure 3. GCMS analysis of MC252 oil and oil-contaminated sediment. (A) GCMS chromatogram of 10 ppm Macondo oil (MC252); (B) concentrations of $n$-alkanes in tar balls and sediment from July Marsh samples as determined by GCMS. doi:10.1371/journal.pone.0041305.g003

measurements were performed by Envirochem Environmental Laboratories, Mobile, AL.

\section{Results}

\section{Site Water Parameters}

Water quality parameters measured during the June, July, and September 2010 sampling periods are summarized in Table 1.
Water temperature averaged $33^{\circ} \mathrm{C}$ over the four month time period $(\sim 1 \mathrm{~m}$ depth). Salinity ranged between 15 and $17 \mathrm{ppt}$ in June and July and increased to $22 \mathrm{ppt}$ in September. Dissolved oxygen saturation (DO) was highest (141\%) in June and lowest in July (84\%). DO increased to $110 \%$ in September 2010 (Table 1). Turbidity correlated with salinity and $\mathrm{pH}$ ranged between 7.5 and 8.5 . 
Table 3. Number of bacterial OTUs detected by PhyloChip in Inlet and Marsh sediments for June, July, and September 2010.

\begin{tabular}{|c|c|c|c|c|c|c|c|c|c|c|c|c|}
\hline \multirow[b]{2}{*}{ Phylum } & \multicolumn{3}{|c|}{ Inlet 0-2 cm } & \multicolumn{3}{|c|}{ Inlet 8-10 cm } & \multicolumn{3}{|c|}{ Marsh $0-2 \mathrm{~cm}$} & \multicolumn{3}{|c|}{ Marsh 8-10 cm } \\
\hline & June & July & September & June & July & September & June & July & September & June & July & September \\
\hline Acidobacteria & 60 & 201 & 161 & 88 & 98 & 105 & 60 & 183 & 68 & 81 & 173 & 114 \\
\hline Actinobacteria & 231 & 734 & 603 & 284 & 329 & 410 & 229 & 770 & 452 & 265 & 657 & 444 \\
\hline Bacteroidetes & 185 & 488 & 555 & 179 & 204 & 134 & 139 & 689 & 75 & 158 & 445 & 154 \\
\hline Chlorobi & 5 & 15 & 17 & 11 & 12 & 12 & 3 & 17 & 9 & 8 & 19 & 12 \\
\hline Chloroflexi & 46 & 139 & 99 & 68 & 71 & 79 & 61 & 158 & 73 & 73 & 169 & 100 \\
\hline Cyanobacteria & 51 & 158 & 122 & 70 & 75 & 52 & 47 & 154 & 36 & 39 & 130 & 76 \\
\hline Firmicutes & 150 & 830 & 1262 & 276 & 312 & 975 & 117 & 1050 & 1560 & 157 & 1013 & 787 \\
\hline Bacilli & 52 & 246 & 514 & 88 & 118 & 461 & 50 & 298 & 714 & 51 & 299 & 330 \\
\hline Clostridia & 98 & 584 & 748 & 188 & 194 & 514 & 67 & 752 & 846 & 106 & 714 & 457 \\
\hline Fusobacteria & 10 & 27 & 16 & 14 & 8 & 5 & 13 & 32 & 2 & 2 & 29 & 3 \\
\hline Gemmatimonadetes & 26 & 66 & 62 & 33 & 38 & 37 & 15 & 58 & 29 & 29 & 63 & 45 \\
\hline Nitrospirae & 5 & 18 & 14 & 11 & 9 & 9 & 4 & 20 & 3 & 5 & 19 & 12 \\
\hline Planctomycetes & 76 & 166 & 117 & 90 & 85 & 79 & 74 & 157 & 45 & 77 & 147 & 97 \\
\hline Proteobacteria & 1140 & 3196 & 3843 & 1441 & 1560 & 1719 & 713 & 3625 & 1019 & 1084 & 2439 & 1684 \\
\hline Alphaproteobacteria & 151 & 720 & 820 & 154 & 138 & 332 & 113 & 903 & 206 & 108 & 457 & 312 \\
\hline Betaproteobacteria & 145 & 411 & 487 & 161 & 182 & 278 & 109 & 452 & 249 & 124 & 320 & 261 \\
\hline Deltaproteobacteria & 164 & 560 & 438 & 244 & 270 & 278 & 159 & 595 & 172 & 209 & 567 & 318 \\
\hline Epsilonproteobacteria & 36 & 54 & 107 & 88 & 98 & 89 & 44 & 90 & 27 & 84 & 104 & 90 \\
\hline Gammaproteobacteria & 642 & 1446 & 1983 & 792 & 869 & 740 & 288 & 1577 & 364 & 558 & 986 & 699 \\
\hline Unclassified & 0 & 1 & 4 & 0 & 1 & 0 & 0 & 3 & 0 & 0 & 1 & 1 \\
\hline Zetaproteobacteria & 2 & 4 & 4 & 2 & 2 & 2 & 0 & 5 & 1 & 1 & 4 & 3 \\
\hline SAR406 & 4 & 26 & 20 & 12 & 13 & 17 & 5 & 25 & 15 & 10 & 24 & 19 \\
\hline Spirochaetes & 16 & 67 & 64 & 31 & 36 & 44 & 19 & 65 & 35 & 20 & 73 & 43 \\
\hline Synergistetes & 3 & 10 & 11 & 4 & 6 & 6 & 3 & 11 & 6 & 2 & 11 & 7 \\
\hline Tenericutes & 8 & 59 & 68 & 18 & 19 & 53 & 12 & 81 & 68 & 17 & 72 & 39 \\
\hline Verrucomicrobia & 36 & 142 & 99 & 35 & 37 & 37 & 34 & 138 & 22 & 26 & 90 & 41 \\
\hline WS3 & 15 & 36 & 28 & 23 & 23 & 25 & 15 & 33 & 17 & 21 & 34 & 23 \\
\hline Other/Unclassified & 66 & 199 & 178 & 109 & 117 & 134 & 62 & 197 & 104 & 98 & 228 & 159 \\
\hline Total & 2133 & 6577 & 7339 & 2797 & 3052 & 3932 & 1625 & 7463 & 3638 & 2172 & 5835 & 3859 \\
\hline
\end{tabular}

doi:10.1371/journal.pone.0041305.t003

\section{Hydrocarbons}

Hydrocarbons were analytically detected in salt marsh sediments in June 2010. During sampling in July 2010, oil was present as a light sheen or mousse floating on the water and tar mats were observed mixed with wrack (organic debris) on the rush stands, marsh fringe, and shoreline. By early September 2010 oil was no longer visible in the water or along the shoreline of the marsh. TPH ranged from below detection (BD) to $189 \mathrm{mg} \mathrm{kg}^{-1}$ in the sediments and was highest at $20,300 \mathrm{mg} \mathrm{kg}^{-1}$ in tar balls (Table 2). TPH was distributed heterogeneously in the Inlet site samples as demonstrated by the wide range of values measured in replicate cores. TPH concentrations in June Inlet replicate cores were BD at the sediment-water interface within the $0-2 \mathrm{~cm}$ sections, however deeper in the core $(8-10 \mathrm{~cm})$ TPH varied from BD to $145 \mathrm{mg} \mathrm{kg}^{-1}$ suggesting that oil was randomly dispersed throughout the Inlet. July Inlet cores demonstrated similar heterogeneity with TPH ranging from BD to $164 \mathrm{mg} \mathrm{kg}^{-1}$ at the surface and $\mathrm{BD}$ to $64 \mathrm{mg} \mathrm{kg}^{-1}$ in subsurface sections. TPH was detected in surficial Inlet sediments in September $\left(\sim 50 \mathrm{mg} \mathrm{kg}^{-1}\right)$, but was BD at $8-10 \mathrm{~cm}$ depth. TPH in the June Marsh samples were more evenly distributed than in the Inlet samples, with TPH concentra- tions above detection in all replicate cores at both the surface and in the subsurface. TPH measurements varied within the replicates from 34 to $189 \mathrm{mg} \mathrm{kg}^{-1}$. July Marsh cores demonstrated a similar trend as June cores at the surface, with TPH ranging from 53 to $163 \mathrm{mg} \mathrm{kg}^{-1}$, but TPH decreased in subsurface sections ranging from BD to $33 \mathrm{mg} \mathrm{kg}^{-1}$. By September $2010 \mathrm{TPH}$ was BD in all Marsh samples.

The range of TPH concentrations in Inlet samples was relatively constant in June, July, and September with the majority $(50 \%)$ of samples ranging from BD to approximately $50 \mathrm{mg} \mathrm{kg}^{-1}$ (Figure 2). In contrast, the range of TPH in Marsh samples was distinctly different between the months with the majority of samples in June having TPH ranging from 50 to $175 \mathrm{mg} \mathrm{kg}^{-1}$. By July, the average TPH concentration decreased between 25 to $55 \mathrm{mg} \mathrm{kg}^{-1}$ and was below detection by September.

Macondo oil (MC252) collected from the wellhead was analyzed by GGMS (Figure 3a). The light crude consisted of $n$-alkanes nonane (C9) to triacontane (C30) with higher concentrations of the short-chain hydrocarbons (C9 to C16) and decreasing concentrations of long-chain hydrocarbons ( 177 to $\mathrm{C} 30)$. The pristane to phytane ratio of the crude oil was approximately 1.0, indicating 
Table 4. Relative abundance (\%) of families of Actinobacteria, Bacteroidetes, and Firmicutes known to contain hydrocarbondegrading species.

\begin{tabular}{|c|c|c|c|c|c|c|c|c|c|}
\hline \multirow[b]{3}{*}{ Phylum } & \multirow[b]{3}{*}{ Class } & \multirow[b]{3}{*}{ Order } & \multirow[b]{3}{*}{ Family } & \multicolumn{6}{|c|}{ Relative Abundance (\%) } \\
\hline & & & & \multicolumn{3}{|l|}{ Inlet } & \multicolumn{3}{|c|}{ Marsh } \\
\hline & & & & June & July & Sept & June & July & Sept \\
\hline \multirow[t]{11}{*}{ Actinobacteria } & Actinobacteria & Actinomycetales & Actinomycetaceae & 0 & 24.7 & 12.6 & 16.7 & 35.8 & 10.2 \\
\hline & & & Brevibacteriaceae & 6.1 & 19.0 & 18.0 & 18.1 & 23.6 & 15.2 \\
\hline & & & Corynebacteriaceae & 12.2 & 16.9 & 17.0 & 14.8 & 20.6 & 18.6 \\
\hline & & & Dietziaceae & 0.0 & 49.9 & 20.6 & 0.0 & 29.5 & 0.0 \\
\hline & & & Gordoniaceae & 16.2 & 16.0 & 18.4 & 11.9 & 23.3 & 14.2 \\
\hline & & & Microbacteriaceae & 7.6 & 22.2 & 18.7 & 12.2 & 25.1 & 14.2 \\
\hline & & & Micrococcaceae & 8.9 & 19.3 & 18.6 & 12.3 & 27.8 & 13.2 \\
\hline & & & Mycobacteriaceae & 7.0 & 19.3 & 16.0 & 11.9 & 31.8 & 13.9 \\
\hline & & & Nocardiaceae & 8.5 & 18.2 & 15.7 & 15.6 & 26.4 & 15.7 \\
\hline & & & Nocardioidaceae & 5.0 & 24.7 & 16.0 & 9.0 & 36.1 & 9.1 \\
\hline & & & Streptomycetaceae & 6.8 & 24.0 & 16.8 & 14.7 & 24.2 & 13.4 \\
\hline \multirow[t]{2}{*}{ Bacteroidetes } & Flavobacteriia & Flavobacteriales & Flavobacteriaceae & 12.2 & 19.4 & 20.8 & 15.5 & 25.6 & 6.4 \\
\hline & Sphingobacteria & Sphingobacteriales & Flexibacteraceae & 9.0 & 21.8 & 15.3 & 17.0 & 27.7 & 9.1 \\
\hline \multirow[t]{7}{*}{ Firmicutes } & Bacilli & Bacillales & Bacillaceae & 4.6 & 9.8 & 26.1 & 6.5 & 13.6 & 39.5 \\
\hline & & & Paenibacillaceae & 2.5 & 9.3 & 37.8 & 6.3 & 14.1 & 30.0 \\
\hline & & & Planococcaceae & 3.8 & 16.6 & 28.8 & 8.2 & 18.4 & 24.2 \\
\hline & & & Staphylococcaceae & 6.3 & 15.2 & 23.3 & 9.9 & 16.8 & 28.5 \\
\hline & & Lactobacillales & Lactobacillaceae & 6.0 & 18.1 & 19.3 & 10.1 & 23.6 & 22.9 \\
\hline & Clostridia & Clostridiales & Clostridiaceae & 4.5 & 12.4 & 20.4 & 7.7 & 19.7 & 35.1 \\
\hline & & & Peptococcaceae & 9.8 & 15.8 & 18.6 & 11.9 & 21.5 & 22.3 \\
\hline \multicolumn{4}{|c|}{ Overall relative abundance of entire bacterial community } & 10.2 & 19.0 & 19.8 & 13.2 & 23.0 & 14.7 \\
\hline
\end{tabular}

doi:10.1371/journal.pone.0041305.t004

minimal weathering of the oil $[33,34]$. In contrast, the concentrations of $n$-alkanes in tar balls and sediments in July Marsh samples demonstrated a highly weathered signature with a pristane to phytane ratio of 0.21 (Figure $3 \mathrm{~b}$ ). Short-chain alkanes were undetected in tar balls and long-chain alkane concentrations steadily increased between C17 and C30.

\section{Bacterial Community Structure}

Within salt marsh sediments, PhyloChip microarray-based analysis identified 12,018 distinct bacterial operational taxonomic units (OTUs) representing 77 phyla using the criteria in Hazen et al. (2010) (Data S1). The number of OTUs in the most abundant phyla is listed in Table 3 (see Table S1 for the complete list of detected phyla). Distinctive trends in the distribution of OTUs were observed during the 3-month time periods. The total number of OTUs in Inlet samples increased between June, July, and September, whereas the total number of OTUs in Marsh samples increased between June and July, but decreased in September. This same trend was observed within many of the individual phyla where Firmicutes and Tenericutes demonstrated the highest fold changes between June and September in Inlet samples increasing by approximately 8.5 -fold in surficial samples $(0-2 \mathrm{~cm})$ and 3-3.5fold in subsurface $(8-10 \mathrm{~cm})$ samples. The majority of dominant phyla in Marsh samples increased in number of OTUs in July but then decreased in September. Bacteroidetes increased by 5 -fold between June and July but subsequently decreased by 9 -fold in September. Other phyla, such as Proteobacteria and Tenericutes increased by 5 - and 7-fold, respectively, in July, and decreased only by 3.6- and 1.2-fold in September. In contrast, Firmicutes did not display a decrease between July and September, but continued to increase in Marsh 0-2 cm sediments by 13-fold between June and September. Surficial sediments tended to have a higher number of OTUs than subsurface and Inlet and Marsh samples had comparable distribution of OTUs within the phyla.

Family-level identification of previously described hydrocarbondegrading bacteria [35] (7082 OTUs) and their individual relative abundances (based on mean fluorescence intensities) in Inlet and Marsh sediments are summarized in Tables 4 and 5. Similar trends were observed in the relative abundance of bacteria between June and September as was seen with the relative richness (as determined by number of OTUs). Relative abundance tended to increase between June, July, and September in Inlet samples, however Marsh samples demonstrated an increase in July and a subsequent decrease in September. Exceptions to these trends included members of Firmicutes that increased in both Inlet and Marsh throughout the time period and Actinobacteria that decreased in September Inlet samples.

Non-metric multi-dimensional scaling (nMDS) analysis of the bacterial community based on the mean relative abundance of identified taxa (Figure 4) revealed three different groupings mainly associated by month: Group I (Inlet 0-2 cm June, Inlet 8-10 cm June, and Marsh 0-2 cm June), Group II (Marsh 8-10 cm June, Inlet 0-2 cm July, Inlet 8-10 cm July, Marsh 0-2 cm July, Marsh 8-10 cm July, and Inlet 0-2 cm September), and Group III (Inlet 8-10 cm September, Marsh 0-2 cm September, and Marsh 8-10 September). Analysis of similarities (ANOSIM) denoted significant 
Table 5. Relative abundance (\%) of families of Proteobacteria known to contain hydrocarbon-degrading species.

\begin{tabular}{|c|c|c|c|c|c|c|c|c|}
\hline \multirow[b]{3}{*}{ Class } & \multirow[b]{3}{*}{ Order } & \multirow[b]{3}{*}{ Family } & \multicolumn{6}{|c|}{ Relative Abundance (\%) } \\
\hline & & & \multicolumn{3}{|l|}{ Inlet } & \multicolumn{3}{|c|}{ Marsh } \\
\hline & & & June & July & Sept & June & July & Sept \\
\hline \multirow[t]{10}{*}{$\alpha$-proteobacteria } & Caulobacterales & Caulobacteraceae & 5.2 & 16.9 & 27.4 & 9.6 & 28.3 & 12.7 \\
\hline & Rhizobiales & Beijerinckiaceae & 4.2 & 20.5 & 29.4 & 8.5 & 27.0 & 10.5 \\
\hline & & Brucellaceae & 6.4 & 13.4 & 33.2 & 10.8 & 25.8 & 10.3 \\
\hline & & Hyphomicrobiaceae & 7.7 & 18.6 & 18.5 & 12.6 & 30.8 & 11.8 \\
\hline & & Rhizobiaceae & 4.1 & 16.8 & 28.5 & 9.1 & 31.4 & 10.0 \\
\hline & & Xanthobacteraceae & 11.6 & 15.7 & 23.1 & 11.5 & 33.5 & 4.7 \\
\hline & Rhodospirillales & Acetobacteraceae & 6.0 & 15.4 & 21.3 & 10.2 & 22.6 & 24.5 \\
\hline & & Rhodospirillaceae & 8.0 & 19.6 & 20.4 & 12.6 & 26.5 & 12.9 \\
\hline & Sphingomonadales & Erythrobacteraceae & 4.2 & 20.2 & 25.5 & 9.0 & 32.9 & 8.2 \\
\hline & & Sphingomonadaceae & 7.1 & 18.7 & 23.0 & 11.9 & 26.3 & 13.0 \\
\hline \multirow[t]{4}{*}{ B-proteobacteria } & Burkholderiales & Alcaligenaceae & 8.8 & 18.3 & 22.9 & 9.9 & 20.8 & 19.3 \\
\hline & & Burkholderiaceae & 6.7 & 13.6 & 25.9 & 12.2 & 24.6 & 17.0 \\
\hline & & Comamonadaceae & 10.2 & 17.6 & 19.3 & 13.9 & 22.5 & 16.5 \\
\hline & Rhodocyclales & Rhodocyclaceae & 9.4 & 14.4 & 25.2 & 12.0 & 18.0 & 21.1 \\
\hline \multirow[t]{2}{*}{$\delta$-proteobacteria } & Desulfuromonadales & Geobacteraceae & 8.2 & 21.5 & 17.3 & 12.8 & 28.7 & 11.5 \\
\hline & Syntrophobacterales & Desulfobacteraceae & 13.4 & 20.2 & 15.3 & 15.7 & 24.5 & 10.8 \\
\hline \multirow[t]{18}{*}{$\gamma$-proteobacteria } & Aeromonadales & Aeromonadaceae & 15.0 & 40.6 & 20.3 & 8.4 & 9.8 & 5.9 \\
\hline & Alteromonadales & Alteromonadaceae & 14.5 & 14.8 & 29.6 & 20.0 & 13.0 & 8.1 \\
\hline & & Colwelliaceae & 22.1 & 15.6 & 24.7 & 15.9 & 14.6 & 7.0 \\
\hline & & Pseudoalteromonadaceae & 19.2 & 22.3 & 20.1 & 13.1 & 18.0 & 7.4 \\
\hline & & Shewanellaceae & 26.4 & 27.2 & 17.8 & 17.3 & 8.4 & 2.9 \\
\hline & Enterobacteriales & Enterobacteriaceae & 13.6 & 22.3 & 21.0 & 14.5 & 18.0 & 10.6 \\
\hline & Oceanospirillales & Alcanivoracaceae & 10.1 & 16.3 & 26.9 & 15.7 & 16.7 & 14.2 \\
\hline & & Alteromonadaceae & 8.9 & 19.4 & 20.8 & 14.1 & 26.0 & 10.7 \\
\hline & & Halomonadaceae & 10.9 & 21.1 & 20.7 & 13.0 & 23.7 & 10.5 \\
\hline & & Oceanospirillaceae & 22.9 & 17.8 & 23.3 & 13.1 & 13.2 & 9.7 \\
\hline & & Oleiphilaceae & 11.7 & 16.1 & 28.8 & 13.6 & 15.8 & 13.9 \\
\hline & Pasteurellales & Pasteurellaceae & 9.8 & 19.6 & 24.9 & 16.8 & 21.1 & 7.7 \\
\hline & Pseudomonadales & Moraxellaceae & 9.4 & 17.0 & 23.9 & 12.3 & 21.9 & 15.6 \\
\hline & & Pseudomonadaceae & 15.3 & 21.4 & 26.7 & 12.0 & 13.7 & 10.9 \\
\hline & Thiotrichales & Piscirickettsiaceae & 9.2 & 13.5 & 28.1 & 13.9 & 17.8 & 17.6 \\
\hline & & Thiotrichaceae & 9.2 & 17.9 & 20.7 & 16.4 & 22.5 & 13.3 \\
\hline & Vibrionales & Vibrionaceae & 15.6 & 19.5 & 17.3 & 14.6 & 26.7 & 6.3 \\
\hline & Xanthomonadales & Xanthomonadaceae & 8.9 & 12.4 & 33.2 & 10.5 & 15.8 & 19.1 \\
\hline \multicolumn{3}{|c|}{ Overall relative abundance of entire bacterial community } & 10.2 & 19.0 & 19.8 & 13.2 & 23.0 & 14.7 \\
\hline
\end{tabular}

$(\mathrm{R}=1.0 ; \mathrm{p}=0.01)$ differences between the three groups. The overall relative bacterial abundances of these groups (Figure 5) indicated the taxa responsible for these significant differences. Firmicutes increased between Group I and Group III, with members of the classes Bacilli and Clostridia increasing in relative abundance by over 2-fold. Tenericutes and Betaproteobacteria additionally increased in relative abundance by $\sim 1.5$-fold each. Phyla that decreased in relative abundance from Group I to Group III were Verrucomicrobia (2.3-fold), Bacteroidetes (2.3-fold), Cyanobacteria (1.8-fold), Planctomycetes (1.8-fold), Gammaproteobacteria (1.3-fold), and Acidobacteria (1.4-fold).

\section{Functional Gene Analysis}

GeoChip microarray-based analysis identified 16,383 unique functional genes in 13 gene categories within salt marsh sediments (Data S2). Overall Inlet functional gene signal intensities showed moderate differences $(\mathrm{R}=0.268 ; \mathrm{p}<0.01)$ from functional genes detected in Marsh sediments between June and July 2010. The normalized signal intensity representing the relative abundance of all genes within specific categories in Inlet and Marsh samples were compared between June and July (Figure 6). Inlet functional genes within the categories of carbon cycling, metal resistance, organic remediation, and stress increased in July compared to June sediments, but were not significant $(\mathrm{p}>0.05)$. In contrast, Marsh 


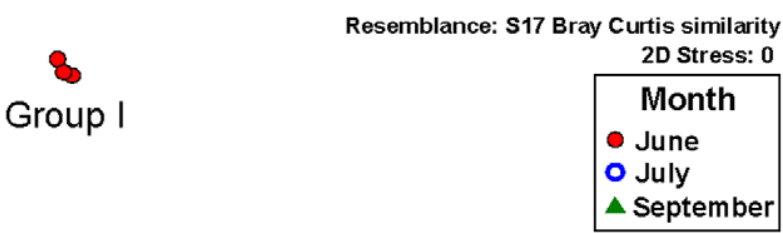

\section{Group II}

\section{Group III}

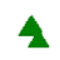

Figure 4. Non-metric multi-dimensional scaling (nMDS) ordination of the bacterial community in salt marsh sediments. Resemblance matrix generated using Bray Curtis similarity and based on the relative abundance of taxa identified by PhyloChip analysis. doi:10.1371/journal.pone.0041305.g004

sediment functional genes significantly decreased $(\mathrm{p}<0.05)$ between June and July in all functional gene categories, specifically carbon cycling, organic remediation, and stress.

Distinctive trends were observed in the average signal intensities of genes related specifically to hydrocarbon degradation in Inlet (Figure 7) and Marsh (Figure 8) sediments. Genes involved in hydrocarbon degradation increased in relative abundance between June and July in Inlet sediments but decreased in Marsh sediments. Genes known to degrade alkanes, cycloalkanes, aromatic carboxylic acids, chlorinated aromatics, polycyclic aromatics, and other aromatics decreased significantly $(\mathrm{p}<0.01$ and $\mathrm{p}<0.05)$ in Marsh samples between June and July during the time oil concentrations were decreasing in Marsh sediments. In contrast, genes related to hydrocarbon degradation increased in signal intensities between June and July in Inlet sediments though not significantly $(\mathrm{p}>0.05)$.

\section{Discussion}

Salt marshes ecosystems are highly productive and biologically rich environments that are sensitive to anthropogenic contamination such as oil spills [36,37]. The overall impact to the system depends on the amount and type of oil, physical aspects of the marsh, and temperature. The Deepwater Horizon oil spill occurred approximately $77 \mathrm{~km}$ offshore during the late spring and by the time the oil reached the Alabama coast [6] in the early summer it presented primarily as weathered tar balls and/or mousse collecting within salt marsh sediments and along the shore. We detected oil in the Point Aux Pins salt marsh sediments in June 2010 that persisted through our samplings in September 2010. The amount of oil that affected the Alabama marsh was heterogeneously distributed and did not saturate the sediments as was observed in areas of coastal Louisiana [38]. Oil saturated sediments can form "pavements" that sink into the subsurface [39]. These reduced water-oil interfaces effectively preserve oil from microbial biodegradation and can remain sequestered for years. Analysis of sediment cores collected one year after the arrival of oil in the Point Aux Pins salt marsh detected no TPH within the top $30 \mathrm{~cm}$ of sediments (data not shown). The absence of "pavements" within this depth profile suggests that the heterogeneity and amount of oil in the sediment did not appear to favor oil preservation and may have been a key factor that contributed to the efficient removal of oil from these marsh sediments possibly by natural attenuation.

The relative distribution of the predominant bacterial phyla detected was approximately 7\% Bacteroidetes; $11 \%$ Actinobacteria; 16\% Firmicutes; and 46\% Proteobacteria (Table 3). Dominance of Proteobacteria is consistent with the phylogenetic diversity observed

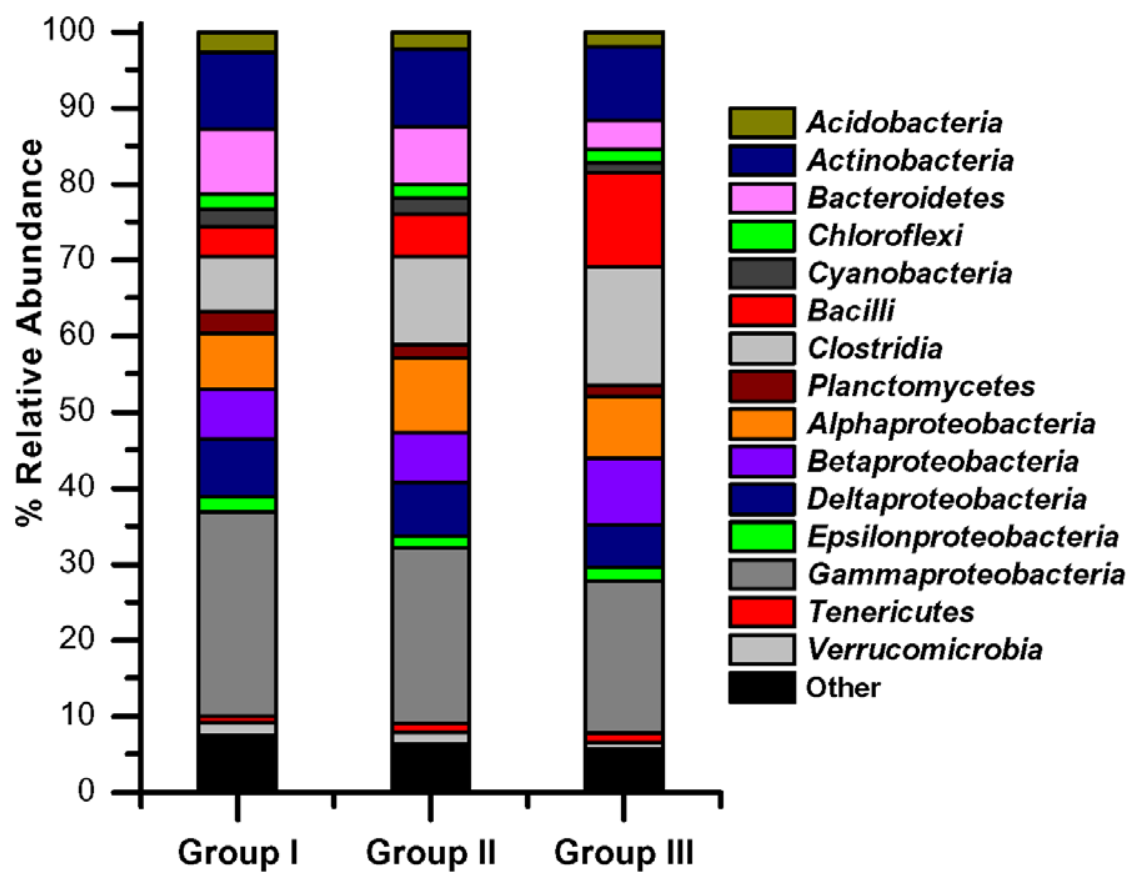

Figure 5. Relative abundance of phyla in salt marsh sediments. Groups I, II, and III determined from nMDS analysis. doi:10.1371/journal.pone.0041305.g005 


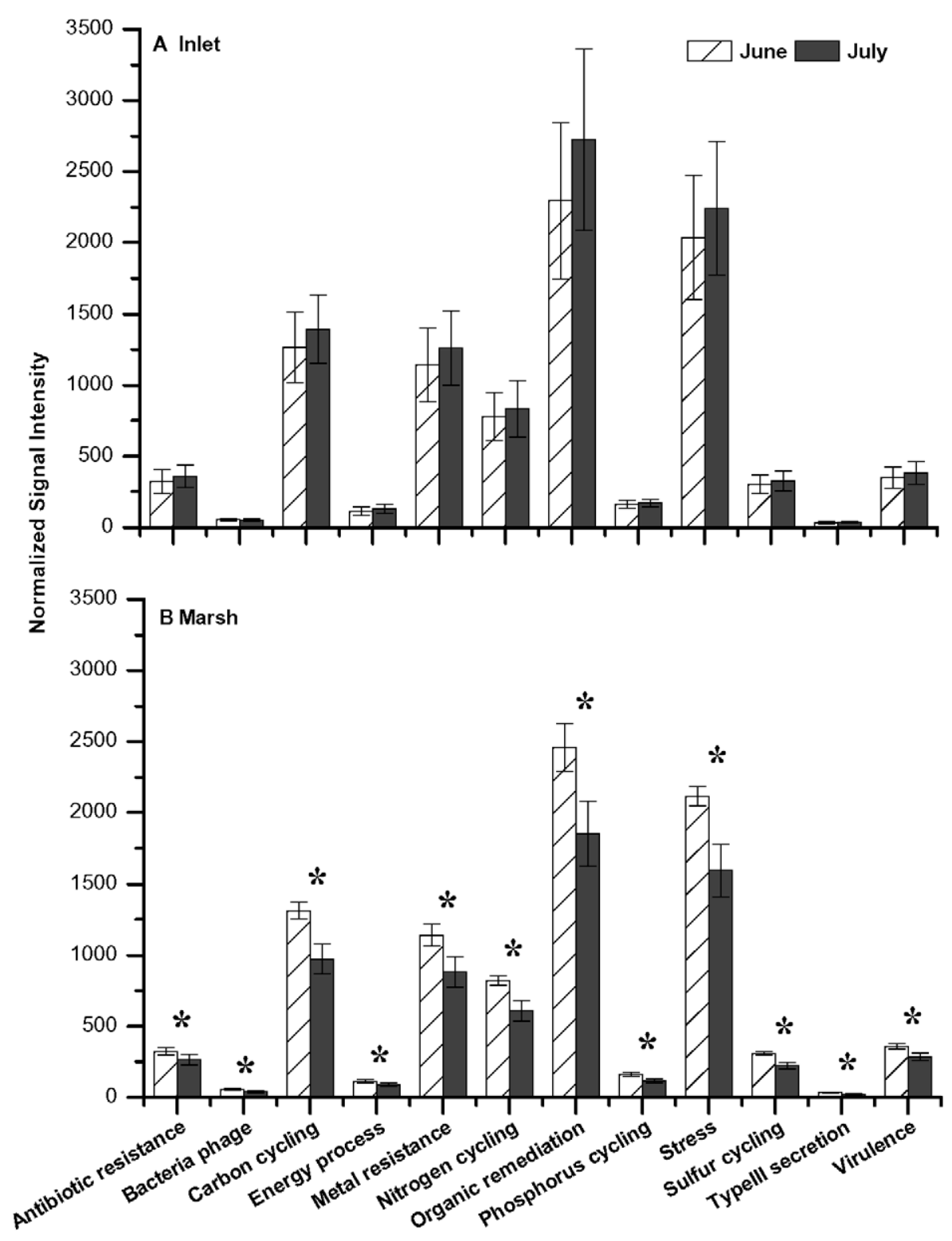

Figure 6. Functional gene distribution in Inlet and Marsh sediments. Gene relative abundance determined by GeoChip for samples compared between June and July 2010. Categories with significant changes indicated by $*$ for $p<0.05$. doi:10.1371/journal.pone.0041305.g006

in other estuarine salt marshes $[43,44,45]$ and a Florida sandy beach impacted by the Deepwater Horizon oil spill [23]. Both the relative abundance and number of OTUs of bacterial phyla increased during oiling, suggesting that not only did the relative community richness increase in response to the hydrocarbon input, but the relative intensities of those populations already at detectable levels responded as well. Members of hydrocarbondegrading bacterial families that demonstrated the largest increases in relative abundance between June and July during the oiling of sediments were Actinomycetaceae, Dietziaceae, Nocardioidaceae, Rhizobiaceae, Xanthobacteraceae, Erythrobacteraceae, and Aeromonadaceae. Members of these families have been shown to degrade alkanes [46] and polynuclear aromatic hydrocarbons (PAHs) $[47,48,49,50]$. Interestingly, several hydrocarbon-degraders detected in the salt marsh, such as Aeromonadaceae, Bacillaceae, Pseudomonadales, and Shewanellaceae, are also known to form biofilms and/or produce biosurfactants $[51,52,53,54,55,56]$ that can enhance oil degradation through gene transfer and oil emulsification $[54,57,58]$.

Ordination of the bacterial community based on relative abundance revealed distinctive differences between groups of samples based primarily on month during the oil inundation (Figure 4). Increases in relative abundance of known hydrocarbon degraders, such as Actinobacteria, Bacteroidetes, and Proteobacteria, between June and July when oil concentrations were highest and subsequent decreases in September when concentrations were lower suggest a rapid microbial response to oil concentrations. In contrast, both Bacilli and Clostridia demonstrated significant increases in relative abundance in September. Classes of known hydrocarbon-degrading Firmicutes steadily increased in all samples between June and September even after oil was no longer detected in contrast to other hydrocarbon degraders that immediately declined when the oil was undetectable. Community enrichment of Firmicutes in salt marsh sediments has also been observed in 


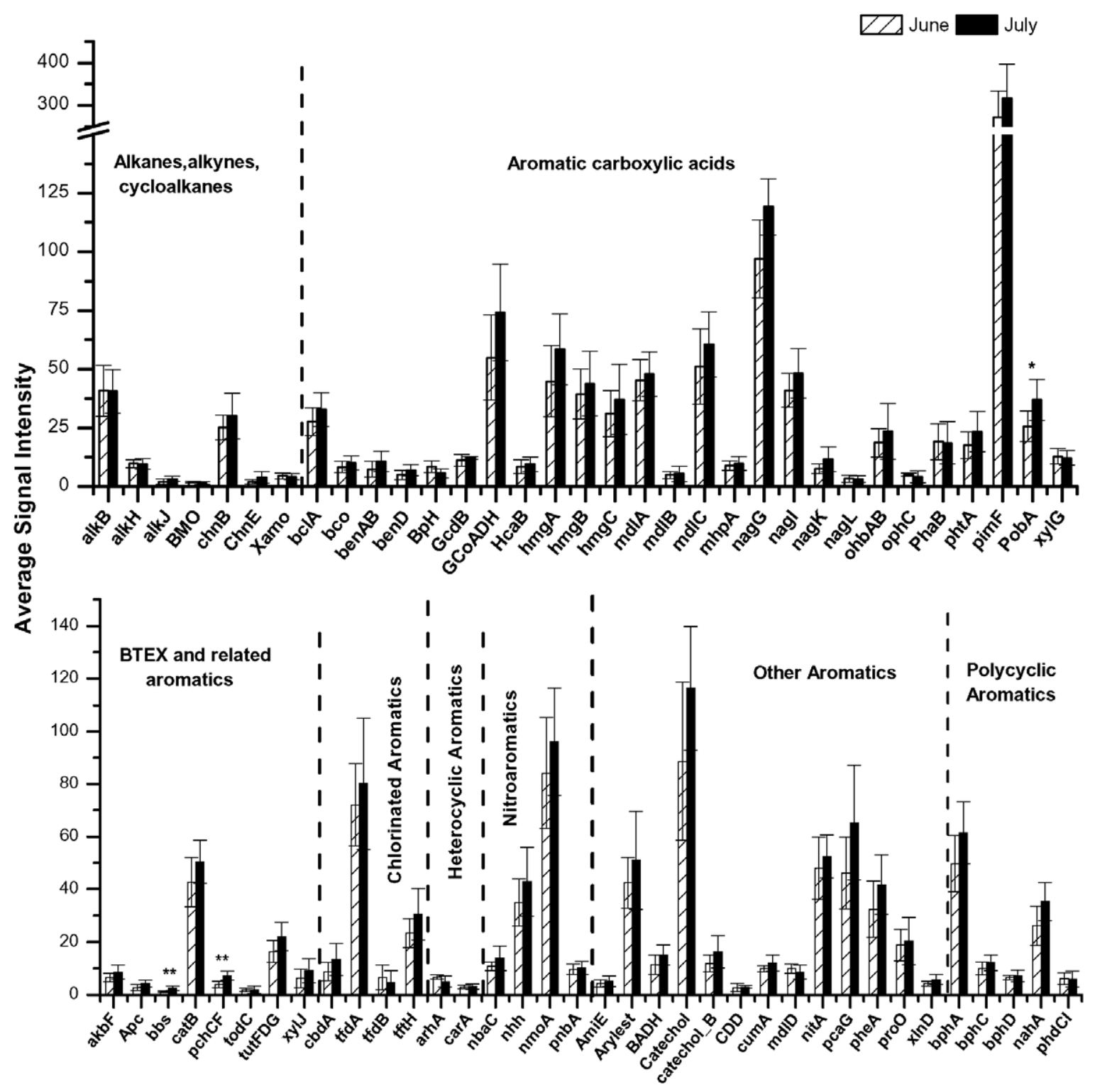

Figure 7. Hydrocarbon degradation genes in Inlet sediments. Average abundances of hydrocarbon degradation genes in Inlet sediments compared between June and July. Significant changes indicated by ${ }^{*}$ for $p<0.05$ and ${ }^{* *}$ for $p<0.01$.

doi:10.1371/journal.pone.0041305.g007

response to hydrocarbon contamination in a simulated spill study [59] and may be used as an indicator of the later stages of hydrocarbon degradation when more recalcitrant compounds such as PAHs are present [23].

The function of the microbial community in salt marsh sediments also changed during the time of oiling. The overall microbial community functional structure was significantly $(\mathrm{p}<0.01)$ different between Marsh and Inlet sediments during the months of June and July when TPH concentrations were increasing in the Inlet and decreasing in the Marsh. While total functional gene relative abundances increased $(12.7 \%)$ in Inlet samples between June and July in correlation with a $44 \%$ increase in total TPH, genes significantly $(\mathrm{p}<0.05)$ decreased by $25.2 \%$ in Marsh sediments where total TPH decreased by $36 \%$ in July compared to June (Figure 6; Table 2). This positive relationship between gene abundance, particularly hydrocarbon-degrading genes, and TPH suggests that community function was driven by oil concentrations. This association is further supported by an associated decrease in relative abundance of known hydrocarbondegrading bacteria, specifically members of Alteromonadaceae, Colwelliaceae, and Shewanellaceae, between June and July in Marsh sediments. Significant $(\mathrm{p}<0.05)$ associations were observed between TPH and genes involved in degrading alkanes, alkynes, cycloalkanes, aromatic carboxylic acids, chlorinated aromatics, polycyclic aromatics, and other aromatics (Figure 8) suggesting that these genes were actively involved in degrading the oil that impacted the salt marsh. Similar findings have been reported in which hydrocarbon degrading genes were enriched in a deep-sea Deepwater Horizon oil plume [24,27].

The salt marsh vegetation appeared to act as traps for the oil coming ashore. Oil was visible on marsh grass leaves and higher concentrations were detected within the Marsh sediments compared to the open Inlet during the early months of impact (Figure 2). Oil in the Marsh sediments, however, decreased 


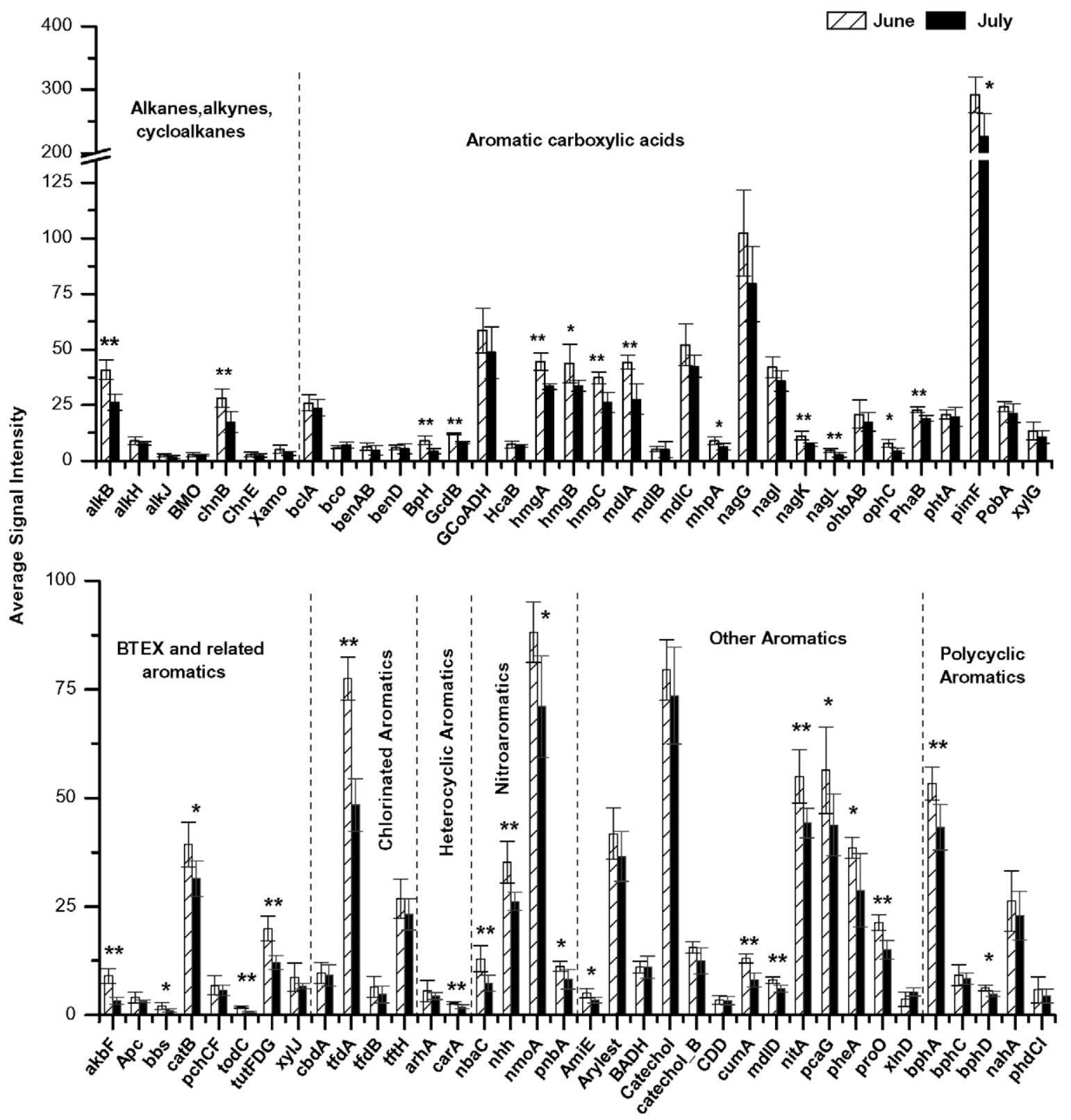

Figure 8. Hydrocarbon degradation genes in Marsh sediments. Average abundances of hydrocarbon degradation genes in Marsh sediments compared between June and July. Significant changes indicated by ${ }^{*}$ for $p<0.05$ and ${ }^{*}$ for $p<0.01$.

doi:10.1371/journal.pone.0041305.g008

significantly within one month and was no longer detected by September 2010, whereas oil in the Inlet sediments increased in July before declining in September. The greater decrease of oil in Marsh sediments compared to the Inlet sediments may have been a result of microbial degradation that was enhanced by the plant rhizosphere. The presence of marsh vegetation, such as $S$. alterniflora [40] and $\mathcal{F}$. roemerianus [41], has been shown to decrease oil concentrations in sediments possibly due to plant uptake, increased aeration in the root zone, and/or production of root exudates that may promote oil mineralization and microbial hydrocarbon degradation. Enzymes, such as laccase, dehalogenase, nitroreductase, nitrilase, peroxidase, and cytochrome P450, supplied by roots and/or associated bacteria have been shown to aid in the detoxification of organic pollutants within the rhizosphere [e.g. 42,60,61]. Indeed, several of the genes that code for these enzymes (phenol oxidase, rd, pbnA, ALN, nitA, lip, mnp, P450, $B p H)$ were significantly $(\mathrm{p}<0.05)$ higher in relative abundance in Marsh sediments compared to the Inlet suggesting a synergistic plant-microbe interaction within the salt marsh that may have been important in hydrocarbon degradation in these sediments.

Anaerobic degradation of hydrocarbons may also have contributed to the removal of oil from the salt marsh sediments. Regardless of oxygen-saturated overlying waters, dissolved oxygen has been shown to diffuse only within the top few millimeters of the sediment-water interface $[62,63,64]$, thereby creating reducing conditions that may contribute to the anaerobic degradation of hydrocarbons in association with sulfate reduction, denitrification, and methanogenesis $[65,66,67,68]$. Genes associated with anaerobic mechanisms, such as sulfate reduction $(d s r A / B)$, methanogenesis $(m c r A)$, and denitrification (narG, nirK, nirS, and nos Z), were 
detected throughout the salt marsh, along with several bacteria known to anaerobically degrade hydrocarbons, such as Rhodocyclaceae, Geobacteraceae, and Desulfobacteraceae (Table 5), suggesting that the anaerobic biodegradation of hydrocarbons could have occurred within the sediments.

Our results indicate that the microbial community structure and function of the coastal salt marsh was altered during the months of oil inundation from the Deepwater Horizon oil spill. The amount of incoming oil, its heterogeneous distribution within the sediments of the salt marsh, warm summer temperatures, and available nutrients may have played key roles in the efficient removal of oil that was undetectable within five months based on our samplings. The significant increase in response to the oil of the indigenous microbial population containing known hydrocarbondegrading bacteria coupled with a subsequent increase in hydrocarbon degradation functional genes provides evidence that in situ bioremediation contributed to the degradation of oil at this site. These results suggest that in highly sensitive environments, such as salt marshes and estuaries that support a naturally occurring hydrocarbon-degrading microbial population, natural attenuation may be a preferable means of remediation to other mechanical strategies that can cause irreparable damage to the habitat. However, further comprehensive microbial studies are needed in Gulf of Mexico areas, where the threat of oil spills is an

\section{References}

1. Atlas RM, Hazen TC (2011) Oil biodegradation and bioremediation: A tale of the two worst spills in US history. Environ Sci Technol 45: 6709-6715.

2. Camilli R, Reddy CM, Yoerger DR, Van Mooy BAS, Jakuba MV, et al. (2010) Tracking Hydrocarbon Plume Transport and Biodegradation at Deepwater Horizon. Science 330: 201-204.

3. Camilli R, Di Iorio D, Bowen A, Reddy CM, Techet AH, et al. (2011) Acoustic measurement of the Deepwater Horizon Macondo well flow rate. Proc Natl Acad Sci USA. DOI: 10.1073/pnas.1100385108.

4. Reddy CM, Arey JS, Seewald JS, Sylva SP, Lemkau KL, et al. (2011) Composition and fate of gas and oil released to the water column during the Deepwater Horizon oil spill. P Natl Acad Sci USA. DOI: 10.1073/ pnas. 1101242108.

5. Operational Science Advisory Team (2011) Summary Report for the Fate and Effects of Remnant Oil Remaining in the Beach Environment. Available: http://www.restorethegulf.gov/sites/default/files/documents/pdf/ Annex \%20B\%20Spatial.pdf. Accessed 8 June 2012.

6. Hayworth JS, Clement TP, Valentine JF (2011) Deepwater Horizon oil spill impacts on Alabama beaches. Hydrol Earth Syst Sc 15: 3639-3649.

7. Mann KH (2000) Ecology of coastal waters: With implications for management. Oxford, England: Blackwell Science, Inc. 406 p.

8. Page DS, Boehm PD, Douglas GS, Bence AE, Burns WA, et al. (1999) Pyrogenic polycyclic aromatic hydrocarbons in sediments record past human activity: A case study in Prince William Sound, Alaska. Mar Pollut Bull 38: 247-260.

9. Burns KA, Garrity SD, Levings SC (1993) How Many Years until Mangrove Ecosystems Recover from Catastrophic Oil-Spills. Mar Pollut Bull 26: 239-248.

10. Hoff RZ (1995) Responding to oil spills in coastal marshes: The fine line between help and hindrance. Seattle, WA USA: NOAA - Report HAZMAT 96-1. 17 p. Available: http://www.fws.gov/contaminants/FWS OSCP 05/ fwscontingencyappendices/N-Manuals-Response-Assessment/CoastalMarshes. pdf. Accessed 8 June 2012

11. Zhu X, Venosa AD, Suidan MT, Lee K (2004) Guidelines for the bioremediation of oil-contaminated salt marshes. Report under a contract with Office of Research and Development, U.S. Environmental Protection Agency. Available: http://www.epa.gov/oem/docs/oil/edu/saltmarshbiormd.pdf. Accessed 8 June 2012.

12. Gilfillan ES, Maher NP, Krejsa CM, Lanphear ME, Ball CD, et al. (1995) Use of remote sensing to document changes in marsh vegetation following the Amoco Cadiz oil spill (Brittany, France, 1978). Mar Pollut Bull 30: 780-787.

13. Atlas RM (1981) Microbial-degradation of petroleum-hydrocarbons - an environmental perspective. Microbiol Rev 45: 180-209.

14. Amund OO, Adebiyi AG (1991) Effect of viscosity on the biodegradability of automotive lubricating oils. Tribol Int 24: 235-237.

15. Aitken CM, Jones DM, Larter SR (2004) Anaerobic hydrocarbon biodegradation in deep subsurface oil reservoirs. Nature 431: 291-294.

16. Oka AR, Phelps CD, Zhu XY, Saber DL, Young LY (2011) Dual biomarkers of anaerobic hydrocarbon degradation in historically contaminated groundwater. Environ Sci Technol 45: 3407-3414.

17. Mills HJ, Martinez RJ, Story S, Sobecky PA (2004) Identification of members of the metabolically active microbial populations associated with Beggiatoa species ongoing issue, in order to establish base-line microbial and ecological data so that the impacts of oil spills, such as the Deepwater Horizon, may be fully evaluated in the future.

\section{Supporting Information}

Table S1 Total number of bacterial OTUs detected by PhyloChip in Inlet and Marsh sediments in all phyla.

(PDF)

Data S1 Total bacterial OTUs detected by PhyloChip for all samples. Positive fraction and normalized fluorescence intensity values are reported.

(XLSX)

Data S2 Functional gene normalized signal intensities detected by GeoChip.

(XLSX)

\section{Author Contributions}

Conceived and designed the experiments: MJB RJM BM PAS. Performed the experiments: MJB RJM SR JP YMP LMT JDVN. Analyzed the data: MJB RJM YMP LMT GLA TCH JDVN JZ PAS. Contributed reagents/ materials/analysis tools: GLA TCH JZ BM PAS. Wrote the paper: MJB RJM PAS.

mat communities form Gulf of Mexico cold-seep sediments. Appl Environ Microb 70: 5447-5458.

18. MacDonald IR, Leifer I, Sassen R, Stine P, Mitchell R, et al. (2002) Transfer of hydrocarbons from natural seeps to the water column and atmosphere. Geofluids 2: 95-107

19. Martinez RJ, Mills HJ, Story S, Sobecky PA (2006) Prokaryotic diversity and metabolically active microbial populations in sediments from an active mud volcano in the Gulf of Mexico. Environ Microbiol 8: 1783-1796.

20. Sassen R, Brooks JM, Kennicutt MC, Macdonald IR, Guinasso NL (1993) How Oil Seeps, Discoveries Relate in Deep-Water Gulf of Mexico. Oil Gas J 91: 64 69.

21. Roberts HH, Carney RS (1997) Evidence of episodic fluid, gas, and sediment venting on the northern Gulf of Mexico continental slope. Econ Geol Bull Soc 92: 863-879.

22. Horel A, Mortazavi B, Sobecky PA (2012) Responses of microbial community from Northern Gulf of Mexico sandy sediments following exposure to Deepwater Horizon crude oil. Environ Toxicol Chem. DOI: 10.1002/etc.1770.

23. Kostka JE, Prakash O, Overholt WA, Green SJ, Freyer G, et al. (2011) Hydrocarbon-degrading bacteria and the bacterial community response in Gulf of Mexico beach sands impacted by the Deepwater Horizon oil spill. Appl Environ Microb 77: 7962-7974.

24. Lu Z, Deng Y, Van Nostrand JD, He Z, Voordeckers J, et al. (2012) Microbial gene functions enriched in the Deepwater Horizon deep-sea oil plume. ISME J 6: $451-460$.

25. Valentine DL, Kessler JD, Redmond MC, Mendes SD, Heintz MB, et al. (2010) Propane Respiration Jump-Starts Microbial Response to a Deep Oil Spill. Science 330: 208-211.

26. Edwards BR, Reddy CM, Camilli R, Carmichael CA, Longnecker K, et al. (2011) Rapid microbial respiration of oil from the Deepwater Horizon spill in offshore surface waters of the Gulf of Mexico. Environ Res Lett 6. DOI: 10.1088/1748-9326/6/3/035301.

27. Hazen TC, Dubinsky EA, DeSantis TZ, Andersen GL, Piceno YM, et al. (2010) Deep-sea oil plume enriches indigenous oil-degrading bacteria. Science 330 : 204-208.

28. DeSantis TZ, Brodie EL, Moberg JP, Zubieta IX, Piceno YM, et al. (2007) High-density universal 16S rRNA microarray analysis reveals broader diversity than typical clone library when sampling the environment. Microbial Ecol 53: 371-383.

29. National Oceanic and Atmospheric Adminstration Tides \& Currents. Available: http://tidesandcurrents.noaa.gov. Accessed 8 June 2012.

30. He ZL, Gentry TJ, Schadt CW, Wu LY, Liebich J, et al. (2007) GeoChip: a comprehensive microarray for investigating biogeochemical, ecological and environmental processes. ISME J 1: 67-77.

31. He ZL, Van Nostrand JD, Wu LY, Zhou JZ (2008) Development and application of functional gene arrays for microbial community analysis. T Nonferr Metal Soc 18: 1319-1327.

32. Liang Y, Van Nostrand JD, Deng Y, He Z, Wu L, et al. (2011) Functional gene diversity of soil microbial communities from five oil-contaminated fields in China. ISME J 5: 403-413. 
33. Lobao MM, Cardoso JN, Mello MR, Brooks PW, Lopes CC, et al. (2010) Identification of source of a marine oil-spill using geochemical and chemometric techniques. Mar Pollut Bull 60: 2263-2274.

34. Hegazi AH, Andersson JT, Abu-Elgheit MA, El-Gayar MS (2004) Source diagnostic and weathering indicators of tar balls utilizing acyclic, polycyclic and S-heterocyclic components. Chemosphere 55: 1053-1065.

35. Prince RC (2005) The microbiology of marine oil spill bioremediation. In: Ollivier B, Magot M, editors. Petroleum Microbiology. Washington, D.C.: ASM Press. 317-335.

36. Lee RF, Page DS (1997) Petroleum hydrocarbons and their effects in subtidal regions after major oil spills. Mar Pollut Bull 34: 928-940.

37. Andrade ML, Covelo EF, Vega FA, Marcet P (2004) Effect of the Prestige oil spill on salt marsh soils on the coast of Galicia (northwestern Spain). J Environ Qual 33: 2103-2110.

38. Kokaly RF, Heckman D, Holloway J, Piazza S, Couvillion B, et al. (2011) Shoreline surveys of oil-impacted marsh in southern Louisiana, July to August 2010. U.S. Geological Survey Open-File Report 2011-1022. 124 p.

39. Prince R, Atlas RM (2005) Bioremediation of marine oil spills. In: Atlas RM, Philp J, editors. Bioremediation: Applied microbial solutions for real-world environmental cleanup. Washington, DC: ASM Press. 269-292.

40. Lin OX, Mendelssohn IA (1998) The combined effects of phytoremediation and biostimulation in enhancing habitat restoration and oil degradation of petroleum contaminated wetlands. Ecol Eng 10: 263-274.

41. Lin QX, Mendelssohn IA (2009) Potential of restoration and phytoremediation with funcus roemerianus for diesel-contaminated coastal wetlands. Ecol Eng 35: 85-91.

42. Chaudhry Q, Blom-Zandstra M, Gupta S, Joner EJ (2005) Utilising the synergy between plants and rhizosphere microorganisms to enhance breakdown of organic pollutants in the environment. Environ Sci Pollut R 12: 34-48.

43. Burke DJ, Hamerlynck EP, Hahn D (2002) Interactions among plant species and microorganisms in salt marsh sediments. Appl Environ Microb 68: 1157-1164.

44. Wang M, Chen J-K, Li B (2007) Characterization of bacterial community structure and diversity in rhizosphere soils of three plants in rapidly changing salt marshes using 16S rDNA. Pedosphere 17: 545-556.

45. Lasher C, Dyszynski G, Everett K, Edmonds J, Ye W, et al. (2009) The diverse bacterial community in intertidal, anaerobic sediments at Sapelo Island, Georgia. Microbial Ecol 58: 244-261.

46. Yumoto I, Nakamura A, Iwata H, Kojima K, Kusumoto K, et al. (2002) Dietzia psychralcaliphila sp nov., a novel, facultatively psychrophilic alkaliphile that grows on hydrocarbons. Int J Syst Evol Micr 52: 85-90.

47. Hamann C, Hegemann J, Hildebrandt A (1999) Detection of polycyclic aromatic hydrocarbon degradation genes in different soil bacteria by polymerase chain reaction and DNA hybridization. FEMS Microbial Lett 173: 255-263.

48. Juhasz AL, Stanley GA, Britz ML (2000) Microbial degradation and detoxification of high molecular weight polycyclic aromatic hydrocarbons by Stenotrophomonas maltophilia strain VUN 10,003. Lett Apl Microbiol 30: 396-401.

49. Arulazhagan P, Vasudevan N (2011) Biodegradation of polycyclic aromatic hydrocarbons by a halotolerant bacterial strain Ochrobactrum sp. VA1. Mar Pollut Bull 62: 388-394.

50. Edlund A, Jansson JK (2008) Use of bromodeoxyuridine immunocapture to identify psychrotolerant phenanthrene-degrading bacteria in phenanthreneenriched polluted Baltic Sea sediments. FEMS Microbiol Ecol 65: 513-525.
51. Ilori MO, Amobi CJ, Odocha AC (2005) Factors affecting biosurfactant production by oil degrading Aeromonas spp. isolated from a tropical environment. Chemosphere 61: 985-992

52. De la Rosa-Garcia SC, Munoz-Garcia AA, Barahona-Perez LF, GamboaAngulo MM (2007) Antimicrobial properties of moderately halotolerant bacteria from cenotes of the Yucatan peninsula. Lett Apl Microbiol 45: 289-294.

53. Deppe U, Richnow HH, Michaelis W, Antranikian G (2005) Degradation of crude oil by an arctic microbial consortium. Extremophiles 9: 461-470.

54. Costerton JW, Lewandowski Z, Caldwell DE, Korber DR, Lappinscott HM (1995) Microbial Biofilms. Annu Rev Microbiol 49: 711-745.

55. Auger S, Ramarao N, Faille C, Fouet A, Aymerich S, et al. (2009) Biofilm formation and cell surface properties among pathogenic and nonpathogenic strains of the Bacillus cereus group. Appl Environ Microb 75: 6616-6618.

56. Ron EZ, Rosenberg E (2002) Biosurfactants and oil bioremediation. Curr Opin Biotech 13: 249-252

57. Singh R, Paul D, Jain RK (2006) Biofilms: implications in bioremediation. Trends Microbiol 14: 389-397.

58. Bognolo G (1999) Biosurfactants as emulsifying agents for hydrocarbons. Colloid Surface A 152: 41-52.

59. Pearson A, Kraunz KS, Sessions AL, Dekas AE, Leavitt WD, et al. (2008) Quantifying microbial utilization of marsh sediments by using the C-13 petroleum hydrocarbons in salt content of bacterial rRNA. Appl Environ Microb 74: 1157-1166.

60. Schnoor JL, Licht LA, McCutcheon SC, Wolfe NL, Carreira LH (1995) Phytoremediation of Organic and Nutrient Contaminants. Environ Sci Technol 29: A318-A323.

61. Harvey PJ, Campanella BF, Castro PML, Harms H, Lichtfouse E, et al. (2002) Phytoremediation of polyaromatic hydrocarbons, anilines and phenols. Environ Sci Pollut R 9: 29-47.

62. Brendel PJ, Luther GW, III (1995) Development of a gold amalgam voltammetric microelectrode for the determination of dissolved $\mathrm{Fe}, \mathrm{Mn}, \mathrm{O}_{2}$, and $\mathrm{S}(-\mathrm{II})$ in porewaters of marine and freshwater sediments. Environ Sci Technol 29: 751-761.

63. Luther GW, Shellenbarger PA, Brendel PJ (1996) Dissolved organic Fe(III) and $\mathrm{Fe}(\mathrm{II})$ complexes in salt marsh porewaters. Geochim Cosmochim Ac 60: 951960.

64. Taillefert M, Neuhuber S, Bristow G (2007) The effect of tidal forcing on biogeochemical processes in intertidal salt marsh sediments. Geochem T 8:6. DOI: $10.1186 / 1467-4866-8-6$.

65. Cervantes FJ, Dijksma W, Duong-Dac T, Ivanova A, Lettinga G, et al. (2001) Anaerobic mineralization of toluene by enriched sediments with quinones and humus as terminal electron acceptors. Appl Environ Microb 67: 4471-4478.

66. Anderson RT, Lovley DR (2000) Anaerobic bioremediation of benzene under sulfate-reducing conditions in a petroleum-contaminated aquifer. Environ Sci Technol 34: 2261-2266.

67. Phelps CD, Young LY (1999) Anaerobic biodegradation of BTEX and gasoline in various aquatic sediments. Biodegradation 10: 15-25.

68. Heider J, Spormann AM, Beller HR, Widdel F (1998) Anaerobic bacterial metabolism of hydrocarbons. FEMS Microbial Rev 22: 459-473. 